\title{
Combined Use of the Lesson Study and the Criteria of Didactical Suitability for the Development of the Reflection on the own Practice in the Training of Mathematics Teachers
}

\author{
Viviane Beatriz Hummes ${ }^{1}$ \\ Vicenç Font Moll ${ }^{1}$ \\ Adriana Breda ${ }^{1}$ \\ ${ }^{1}$ Universidad de Barcelona (UB), Facultad de Educación, Barcelona, Catalunya, España
}

Received for publication on 21 Dec. 2018. Accepted, after revision, on 11 Jan. 2019.

\begin{abstract}
This work aims to investigate the development of reflection on the practice in the training of mathematics teachers through the design and implementation of a formative activity that combines the use of Lesson Study and Criteria of Didactical Suitability as a methodological tool to organize the reflection of the teacher. In the first part, it is argued that the combined use of the Lesson Study (LS) and Didactical Suitability (CDS) allows to overcome the limitations and extend the advantages of both methodologies and, in the second, we analyse the role of the Criteria of Didactical Suitability in a Lesson Study experience, before that tool has been taught to the participants in the framework of a training course that combines both methodologies. The results show that the Criteria of Didactical Suitability are present in the reflection carried out by the participants in the Lesson Study, although these criteria have not yet been taught.

Keywords: Lesson Study. Criteria of Didactical Suitability. Reflection on the own Practice. Training of Mathematics Teachers.

\section{RESUMO}

Este trabajo tiene como objetivo investigar el desarrollo de la reflexión sobre la práctica en la formación de profesores de matemáticas mediante el diseño e implementación de un dispositivo formativo que combina el uso de los Estudios de Clases y los Criterios de Idoneidad Didáctica como herramienta metodológica para organizar la reflexión del profesor. En la primera parte, se argumenta como el uso combinado del Estudio de Clases y los Criterios de Idoneidad permite superar las limitaciones y ampliar las ventajas de ambas metodologías y, en la segunda, se analiza el papel que tienen los Criterios de Idoneidad Didáctica en una experiencia de Estudio de Clases,
\end{abstract}

Corresponding author: Viviane Beatriz Hummes Email: vivihummes@gmail.com

\begin{tabular}{|l|l|l|l|l|l|}
\hline Acta Scientiae & Canoas & v.21 & n.1 & p.64-82 & jan./fev. 2019 \\
\hline
\end{tabular}


antes de que dicha herramienta haya sido enseñada a los participantes en el marco de un dispositivo que combina ambas metodologías. Los resultados muestran que los Criterios de Idoneidad están presentes en la reflexión realizada por los participantes en el Estudio de Clase, aunque estos criterios aún no se les han sido enseñados.

Palabras-clave: Estudios de Clases. Idoneidad Didáctica. Reflexión sobre la Propia Práctica.

Formación de Profesores de Matemáticas.

\section{INTRODUCTION}

The diverse trends in teacher training propose teacher research and reflection on its practice as a key strategy for professional development and improvement of teaching. Among these trends we highlight Action Research (Elliott, 1993), Reflective Practice (Schön, 1983), and Lesson Study (LS) (Hart, Alston, \& Murata, 2011). The construct Criteria of Didactical Suitability (CDS) (and its breakdown of components and indicators), proposed in the framework of the Onto Semiotic Approach to Cognition and Mathematical Instruction (OSA) (Godino, Batanero, \& Font, 2007), can be used as a methodological tool to organize teacher reflection, as has been done in different training processes in some countries (Font, Breda, \& Pino-Fan, 2017); In this paper, each of these methodologies presents advantages and limitations.

This paper presents part of an investigation whose general objective is to investigate the development of the reflection on the own practice in the training of mathematics teachers through the design and implementation of a training device that combines the use of the LS methodology and the CDS as a methodological tool to organize the reflection of the teacher, so as to produce a synergy between both methodologies. For this, in this article we propose the following specific objectives:

a) To carry out a theoretical study on the LS and CDS, seeking to: 1) understand how each proposes the development of reflection on one's own practice in teacher training and 2) complementarities between the two approaches.

b) Investigate the role of CDS in a LS experience, before the tool has been taught to the participants, as a guide to organize their reflection, within the framework of a training device designed to combine both methodologies, and whose objective in general, the participants design, implement, evaluate and redesign sequences of tasks for their students of basic education.

After this introduction, the theoretical framework used is briefly presented in the first section: the LS methodology and the CDS and a brief review of the literature is made. The second section aims to understand how each of these two methodologies proposes the development of reflection on the own practice in teacher training, seeking complementarities between both. In the third section the methodology used in the investigation is presented; first, the design of the training device that combines the use of the CDS and the LS is explained, and second, the methodology used to analyse the data of the first phase of the implementation corresponding to the LS is explained. In the fourth section, the results are presented and in the fifth a discussion is made about them proposing some final considerations. 


\section{THEORETICAL FRAMEWORK}

In this section, the theoretical framework used is presented: the LS methodology and the CDS tool, and a brief review of the literature is made.

\section{The Methodology Lesson Study}

The Lesson Study (LS) device is a methodology for teacher training developed initially in Japan, which basically consists of the collaborative and careful design of a class, its implementation and direct observation in the classroom, and a subsequent joint analysis (Fernández \& Yoshida, 2004; Lewis, 2002; Murata \& Takahashi, 2002; Wang-Iverson \& Yoshida, 2005; Hart, Alston, \& Murata, 2011). The LS are teacher work methodologies supported by research attitudes and collaborative practices among teachers, who seek, at the same time, the improvement of teaching practice and student learning and the professional development of teachers. One of the virtues of the LS is that it places teachers at the epicentre of their professional activity: the design, implementation and redesign of sequences of tasks with the aim of, first, better understanding the learning of the students on the basis of their own teaching experiences and, second, improve this learning. The idea is for teachers to meet with a common question about their students' learning, to plan a lesson for the student to learn, and to examine and discuss what they observe in the implementation of this lesson. Through multiple iterations of the process, teachers have many opportunities to discuss student learning and how their teaching impacts learning. The LS are basically developed in four stages:

1) Class planning: a group of teachers choose the topics to develop; establishes the objectives for the learning and the development of the students; choose the teaching material; and it points out the expectations about possible answers and the behaviour of the students in front of the proposed questions. 2) Realization and observation of the class: a teacher shares his class while others observe and record the teaching and learning process. The participation of the other members of the group is active in each stage of resolution of the proposed questions, from the understanding of the problem, the establishment of strategies and analysis of the resolution, stimulating the questioning and the discovery of the students. 3) Joint reflection on the recorded data: after the class, the teachers (observed and observers) meet to evaluate the observed teaching processes, reflecting on the attitudes and learning of the students and the teacher during the class. The group makes an analysis of the class, taking into account their perspectives, both teaching and the area itself. 4) Redesign: based on the discussions held in the previous stage, the class plan is restructured. It is applied in another class and a new cycle is started.

Although the literature on LS is extensive worldwide, research under this approach in Brazil (context of our research) is scarce, although it is increasing. Based on a review of the research on LS conducted in Brazil, we have highlighted the one by Felix (2010), in which the author points out the difficulties to apply this methodology with Brazilian teachers, due to its marked individualistic character. In fact, the author did a discussion about his own teaching practice in a public school in São Paulo, but he did not manage 
to form a group of teachers in these schools to apply the methodology of LS, having to resort to an external group to the school that they were not elementary school teachers. Other research that we highlight is that of Coelho, Oliveira \& Vianna (2014) who analysed the contributions of the LS approach in the initial teacher training. As in the case of Felix (2010), the methodology had to adapt since the classes were implemented in a fictitious manner, with the same undergraduate students playing the role of basic students. On the other hand, it also explains a preliminary preparatory experience of the one carried out with the future teachers of mathematics, in which a group of professors of a postgraduate program also had an experience of LS, in which the planned class was experienced with middle school students. On the other hand, Utimura (2015) developed a shared teaching project with an LS approach in a municipal primary school in São Paulo. He analysed the potentialities of the project in a fifth year class and highlighted that the teachers participating in the research evolved both in their mathematical and didactic conceptions and, in this way, they felt more confident to plan and carry out their classes.

\section{The Criteria of Didactical Suitability}

The Criteria of Didactical Suitability (CDS) proposed in the theoretical framework OSA, intend to be a partial response to the following problem: What criteria should be used to design a sequence of tasks, which allow to evaluate and develop the mathematical competence of the students and what changes should be made in your redesign to improve the development of this competence? The CDS can serve first to guide the teaching and learning processes of mathematics and, second, to assess their implementations. The CDS are useful in two moments of the instruction processes. In a first moment, Didactical Suitability are principles that guide "how things should be done". In a second moment, the criteria serve to assess the process of instruction effectively implemented. In the OSA the following Criteria of Didactical Suitability are considered (Font, Planas, \& Godino, 2010): Epistemic Suitability, to assess whether the mathematics being taught is "good mathematics". Cognitive Suitability, to assess, before starting the instruction process, if what you want to teach is at a reasonable distance from what the students know, and after the process, if the acquired learning is close to what was intended to be taught. Interactional Suitability, to assess if the interactions solve doubts and difficulties of the students. Meditational Suitability, to assess the adequacy of the material and temporary resources used in the training process. Emotional Suitability, to assess the involvement (interests and motivations) of the students during the instruction process. Ecological Suitability, to assess the adequacy of the instructional process to the educational project of the centre, the curricular guidelines, the conditions of the social and professional environment.

The operability of the CDS requires defining observable indicators, which allow to assess the degree of suitability of each of them. In Breda \& Lima (2016), Seckel (2016) and Breda, Pino-Fan \& Font (2017) a system of indicators is provided that serves as a guide for the analysis and assessment of didactical suitability, which is designed for an instructional process at any educational stage. Each of these criteria is broken down into components and indicators as a rubric, in order to make them operational. The criteria 
and components of didactical suitability are detailed below (for reasons of space the indicators are not detailed) (Table 1).

Table 1

Criteria and suitability components.

\begin{tabular}{ll}
\hline Didactical Suitability & Component \\
\hline Epistemic & (IE1) Errors, (IE2) Ambiguities, (IE3) Wealth of processes, (IE4) Representatives \\
\hline Cognitive & $\begin{array}{l}\text { (IC1) Previous knowledge, (IC2) Curricular adaptation to individual differences, (IC3) } \\
\text { Learning, (IC4) High cognitive demand }\end{array}$ \\
\hline Interactional & (II1) Teacher-student interaction, (II2) Interaction between students, (II3) Autonomy, \\
(II4) Formative evaluation
\end{tabular}

Based on Breda \& Lima (2016).

In the search carried out, in different databases, taking as criteria the appearance in titles, summaries and keywords of the term "criteria of didactical suitability" (in Spanish, Portuguese or English), completed with other sources of information, for example the review carried out Kaiber, Lemos, \& Pino-Fan (2017), we have found the use of CDS in: 1) different research on teacher training in mathematics, such as those described in Breda (2016), Morales \& Font (2017) or Moreira, Gusmão \& Font (2018), in which said construct is used, but not in the framework of a training device specifically designed to teach Didactical Suitability as a tool to organize the teacher's reflection on his own practice,

2) research on training devices in which the use of Criteria of Didactical Suitability is observed as a content to be explained in order to organize the teacher's reflection on his/ her own practice, in degrees (Seckel, 2016; Seckel \& Font, in press) and postgraduates (Font, Breda \& Pino-Fan, 2017; Giacomone, Godino, \& BeltránPellicer, 2018). Then, given that our research focuses on master's training, we briefly explain how CDS have been used in teacher training master's degrees.

\section{Training courses for the teaching of CDS in teacher training master's degrees}

The design and implementation of training cycles in this modality take the Criteria of Didactical Suitability as a content to be taught with the objective of being used as a guideline to organize the teacher's own practice. For example, in Font, Breda \& Pino-Fan, (2017) a training cycle is explained that, instead of presenting the Didactical Suitability 
as already elaborated principles, creates spaces for its generation as a result of consensus in the group. This cycle is divided into two subjects: Innovation and research on the own practice and Final Master's Project, according to the following sequence:

a) Analysis of cases (without theory): Students are proposed to read and analyse class episodes so that they can make an analysis based on their previous knowledge without providing any guidelines for it. b) Emergence of different types of didactic analysis (descriptive, explanatory and evaluative): The sharing of the analyses carried out by the different groups allows observing how the large group contemplates these three different types of didactic analysis, although each group only contemplates some from them. c) Trends in the teaching of mathematics: The episodes analysed have been selected in such a way that the participants implicitly apply some of the current trends in the teaching of mathematics (Breda, Font \& Pino-Fan, 2018). Afterwards, the participants are observed to have used some of these tendencies implicitly. d) Theory (suitability criteria): It is explained that the Criteria of Didactical Suitability should be understood as principles emanating from the argumentative discourse of the educational community, when it is aimed at achieving a consensus on what can be considered better. It is also explained that for the development of the Didactical Suitability construct, the current trends on the teaching of mathematics, the NCTM principles (2000) and the contributions of the different theoretical approaches of Mathematics Didactics (Godino, 2013; Breda, Font

\& Pino-Fan, 2018). e) Reading and commenting on parts of some final master's work from previous courses in which future teachers of previous courses used the Criteria of Didactical Suitability to assess the didactic unit they implemented. f) In the Practical and Master Final Work subjects, students will use CDS to assess their own practice, specifically the unit they have designed and implemented. They have to do a redesign and improve some of the aspects that the evaluation indicates that they should and can improve.

\section{COMPLEMENTARITIES BETWEEN BOTH APPROACHES}

The design of the training devices that aim to teach the use of CDS is based on the assumption, observed in various researches (Breda, 2016), that CDS function as regularities in teachers discourse, when they have to design and/or assess teaching sequences aimed at improving the processes of teaching and learning of mathematics, even without having been taught the use of this tool to guide their reflection. Therefore, it is assumed that, in the initial phases of these training devices, participants formulate and implicitly use some CDS indicators and components. This assumption has worked as a regularity in the various experiences carried out, but in them it has become evident that this initial phase of unpatterned reflection is relatively short and that it would be convenient to have a wider one. On the other hand, the methodology of the LS, in a certain way, can be considered as a very broad unpatched reflection phase that is oriented to the improvement of the teaching and learning process of mathematics, therefore, it is expected that in the planning phase, the observation phase, the reflection phase and the improvement-oriented redesign, the participants implicitly use many of the CDS indicators 
and components to make positive assessments of some aspects of the experience carried out. For example, Felix (2010, p.1) states the following:

[...] although we live the difficulty of applying projects, such as ours, in the public education system (class tradition without student participation, individualism, etc.), we manage to establish positive results that are reflected in the research, which include: a greater interest of the students in the classroom, change of position in the teacher-student relationship, lower indiscipline index, gradual improvement of student grades, effective participation of students with greater learning deficits, higher confidence of the students in relation to the result obtained by them.

We can see that the author is making a positive assessment of certain aspects observed in the LS experience performed. In particular, it is implicitly using the indicator "presents a selection of interesting tasks for the students" of the component "interests and needs" of the criteria of emotional suitability, since it positively values the fact of having managed to increase the interest of the students; or the indicator "facilitates the inclusion of students during class dynamics avoiding exclusion" of the teacher-student interaction component of the criteria of interactional suitability (since it considers positive the effective participation of students with learning deficits); or the indicator "promotion of self-esteem, avoiding the rejection, phobia or fear of mathematics" of the emotion component of the criteria of emotional suitability (since it considers that students have been given greater confidence in themselves).

Therefore, in an LS experience, implicit consensus will arise among the participants about aspects that are valued positively, which can be reinterpreted in terms of indicators and components of the CDS. In other words, the LS methodology can become a type of training model that facility that some of the indicators and components of the CDS arise as consensus of the reflection of the group of teachers, which leads to the expansion of the LS with a training cycle that introduces the indicators, components and Criteria of Didactical Suitability (as is done in the training experiences discussed above).

The formative devices that the CDS intend to teach also start from the assumption that they can be taught as a tool to organize teacher reflection and, therefore, most of the training cycle is dedicated to implementing a teaching and learning process these notions with the participants. On the other hand, in LS, this process of generating a pattern organized in criteria, components and indicators as a tool to organize reflection is not carried out. Therefore, if the LS methodology can be very useful to improve the initial phase of the CDS methodology, the latter can be an extension of the LS methodology to generate a guideline to organize the teacher's reflection.

\section{METHODOLOGY}

This research, of an exploratory and analytical-interpretative nature, seeks to analyse the extent to which a training device based on LS and CDS promotes the reflection of 
practicing mathematics teachers on the design, implementation, evaluation and redesign of task sequences.

To this end, an ad hoc design and implementation of a training device was carried out that combines both methodologies, which served as a case study, with practicing professors participating in a professional master's degree in mathematics teaching in a public institution of higher education located in the south of Brazil. The design was made by the three authors of this work and the implementation by the first author.

The structure of the training device that allows combining the LS with the CDS is as follows: 1) First stage: Lesson Study; 2) Second stage: Observing the participants that in the phase of the Lesson Study they have used explicitly or implicitly some of the components and indicators of the CDS, 3) Third stage: Teaching of the CDS and 4) Fourth stage: Use of the CDS as a methodological tool that allows to organize and improve the reflection made in the phase of the LS, which has repercussions on better proposals for redesigning the sequence of tasks made in the LS.

Participated in the research 13 students of a professional master's course Programa de Pós Graduação em Ensino de Matemática of a state university located in southern Brazil. All were teachers of secondary school mathematics in public or private schools in different cities of the state of Rio Grande do Sul, Brazil. The teachers participated voluntarily by signing a letter of commitment, having been informed of the research objectives and how their productions would be used.

Five weekly meetings of an hour and a half were made with the group of participating teachers (in addition to this presential part, the participants did an autonomous work on their own). Given the objectives set out in this research, in the design and implementation of the training device the emphasis was placed on the first stage (realization of an LS); in particular, the first four sessions were devoted to developing three of the four phases of LS: inquiryplanning; execution-observation; and review-reflection. In the first meeting, the LS methodology was presented to the participants (previously they had already read about this methodology as autonomous work). Since a LS develops with a group of less than thirteen teachers and, with the expectation of obtaining different results, the large group was subdivided into three subgroups. A group with five teachers and the other two with four each. The teachers themselves took the initiative to group themselves according to the affinities between them. It should be noted that it was a group that already knew each other and that already had experience of collaborative work.

In the first meeting, the teachers chose the topic and started the planning of the classes, and also the teacher who would teach the class observed. They also agreed on how the class would be observed: recorded class (the teacher would make a video recording of his own class); or members of each group would go to the educational institution where the implementation would take place; or both possibilities. The teachers agreed to bring resources and materials to continue with the planning of the didactic sequence in the next meeting. 
In the second meeting some minimum guidelines for the realization of class planning were explained (each task should have objectives and expected learning, a brief justification of why to perform the task, etc.). In addition, teachers should explain in the planning how they would work each activity (methodology/didactics). The discussions of the groups in this phase of design and planning of the class were recorded through voice recordings and with observations of the field diary of the researcher who had the role of teacher of the training device implemented.

The third meeting was the day in which the planned class was taught, which was recorded on video, so that later teachers could analyse it and reflect on it. In the fourth meeting, the teachers of each group watched the videos of the class implemented, analysed it and reflected on what could be improved in future implementations.

In the fifth meeting, the other three stages of the training device were condensed, which allows combining the LS with the CDS. First, the criteria that they used in the four previous meetings were highlighted and they were made to observe that they used, explicitly or implicitly, some of the components and indicators of the LS. They were then told that the criteria they used are part of a much broader and more detailed list of criteria and components that should be taken into account for the planning, development and redesign of a mathematics teaching class; At this time, the Criteria of Didactical Suitability were presented and readings and videos were provided to them to autonomously deepen the knowledge of this construct. Finally, they were proposed to redesign the sequence of tasks of their LS taking into account the criteria, components and indicators of the CDS (they had to deliver the redesign online as the last stage of the subject of the master they were doing). For data collection, observation records were used in field journals, video and voice recordings and reflexive interventions during the training cycle process.

The data analysed are those of the first stage of the training device (corresponding to the LS), in which the participating teachers designed, implemented and analysed a didactic sequence. In this sense, the LS subserve the organization and collection of the data, allowing to identify the CDS implicit in the teachers' discourse in all phases of the LS implemented. Basically, the methodology consists of selecting paragraphs in the reflection of the teachers that can be considered evidence of implicit use of some of the indicators and components of the different CDS.

\section{RESULTS}

The results that we expected were, above all, to show how, in the LS stage, some of the components and indicators of the Suitability Criteria appear implicitly in the reflections of the participants. In this sense, we have found evidence that allows us to affirm that the expected results have been obtained. In particular, in the planning phase of the class and in the phase of joint reflection on the data collected, where the participants try to justify that the didactic proposal they develop represents an improvement in the teaching of mathematics. 
Although the thirteen teachers were divided into three groups, two of four and one of five participants, in this paper we will consider only the data collected during the planning and analysis of the class of one of the participating groups, composed of the professors $\mathrm{F}, \mathrm{G}, \mathrm{J}$ and $\mathrm{S}$.

\section{Reflection in Planning}

In the planning phase of the class, we proposed that the teachers elaborate a class that they consider a good class and we invite them to discuss and elaborate a didactic proposal that would mean a change or an innovation on their own practice.

The group chose Professor F. to teach the class. The chosen topic was Linear Function, because it was the subject that he was going to approach with his students of the first year of secondary education (Brazil), at that moment of the course. Initially, they thought about approaching the study of the graphs of this type of function, using GeoGebra's dynamic geometry software as a construction tool. However, computers were not available to students at the school. In this way, they agreed that the teacher could only design the graphic construction for the whole group of students. The initial idea of the class was to elaborate a problem of daily life that would allow the students to compare which means of transport would be more advantageous, Taxi or Uber.

As expected, it is possible to identify in some fragments of teachers dialogues evidence of the implicit use of some of the indicators and components of Criteria of Didactical Suitability, as shown below.

\section{Epistemic Suitability}

The reflection on the mathematical quality does not appear explicitly in the elaboration of the sequence of tasks, nevertheless, it appears implicitly in some parts of the discourse of the professors. In particular, it is possible to notice a concern to elaborate a sequence of activities that contemplate the realization of processes that are relevant in the mathematical activity - one of the components of the criteria of epistemic suitability - as, for example, the resolution of problems:

G.: We start from the problems and the students must answer things by asking questions.

F. Good idea!

$\mathrm{G} .:$ Are you going to choose the problems?

F .: I had an idea. We will try to make them understand the angular coefficient, when it is increasing and decreasing from the problems, that is, understanding the coefficients of the linear function through problem solving. 
The teachers also use the descriptor "use of different representations", one of the indicators of the component "representative sample of the complexity of the mathematical object that one wants to teach", when they are interested in making use of different modes of expression, in this case, the formula of the function and its graph:

G.: The best would be to define the formula of the functions and then draw them in the GeoGebra in order to analyse what the graphs would look like, and compare the differences between them.

F.: Actually the graph will be an evidence to demonstrate the differences between the functions.

An interest can also be inferred by presenting and connecting different meanings of the pending object (functional and geometric), which can be considered an evidence of the implicit use of the indicator "partial meanings are a representative sample of the complexity of the mathematical notion that is wants to teach", another of the indicators of the component "representative sample of the complexity of the mathematical object to be taught":

S.: What are the specific objectives of the class?

F.: Explore the angular coefficient and the ordinate at the origin. But, I think you should have the objective of identifying the intersection between the two lines that represent the two situations proposed.

S.: Actually, to compare two rates of growth there, right? Although the rates of the two situations are increasing, one is more inclined than the other. So, we work with that there, too. I think the intersection is a consequence.

\section{Cognitive Suitability}

In the following dialogue, where teachers discuss how the use of different representations can facilitate learning, it is also implicit the importance of considering the "prior knowledge" necessary to understand the subject in question that students have:

G.: Do not you think that building a table would help them? In the event that an error occurs. Is that the table helps the student to model the function. One that never had contact with a Linear Function, for example.

F.: But the table helps to model the graph more.

G.: Helps to model the function so that it is understood what is happening. Because the variation is always the same. This is characteristic of the Linear Function.

F.: I do not know. I think they already have a notion of how to graph. 


\section{Interactional Suitability}

We can infer in the teacher's discourse the importance that they give to the "autonomy" of the students, one of the components of the criteria of interactional suitability:

S.: How will the class be?

G.: Are not you going to give them the problem formulated?

F.: Start by exposing the problem.

S.: What problem?

F.: Of the tariffs of...

G.: Can I give you an idea? You present the situation to them. You leave them organized in a group. Let them break their heads! Do not bring it, ready.

\section{Mediational Suitability}

In the teacher's discourse it is possible to find evidence of the implicit use of some indicators and components of the Criteria of Didactical Suitability of means. It can even be said that this is the criteria most present in the planning phase. For example, the "material resources" component is evident in many teachers' dialogues. On the other hand, teachers also show attention to the component "number of students, schedule and conditions of the classroom", when they reflect on whether the number or distribution of students allows to carry out the intended instruction process.

F.: I think, in pairs, it's a lot of people to change all the chairs.

G.: It's a lot of people. Then, perhaps, we group them three by three.

S.: Groups of how many people?

F.: Couples.

S.: Couples are many. They are going to leave 19 .

F.: But it's a lot of people. There is no way to move the chairs. We're going to waste a lot of time.

J.: Then trios.

G.: You can make the GeoGebra graphics on the cell phone.

F.: But they can't use cell phones in class.

G.: It's an exception, right? 
We can also observe reflections on time, one of the components of the Criteria of Didactical Suitability of means, in particular the indicator "Adequacy of the meanings intended to the time available":

S.: Is it an hour and a half that we are going to stay with them?

F.: A priori I will only have one period (45 minutes).

J.: Do you think it's possible? What is enough time to do two activities?

S.: I think it's going to be a long time.

F.: Yes, maybe it's missing, but it's a good kind of work.

\section{Emotional Suitability and Ecological Suitability}

With respect to the indicators of emotional suitability and ecological suitability, it was not possible to identify any reference in the extracts from the dialogues analysed.

\section{Reflection on the analysis of the class}

In the phase of the analysis about the class, the teachers of the chosen group made a discussion/reflection about the class implemented by Professor F., but tried to be moderate in criticizing his classmate, being the he who most argued the reasons why the class could be improved.

\section{Epistemic Suitability}

The reflection carried out by the group, as far as the epistemic suitability, is concentrated in the idea that the teacher must have mastery of the content, although they do not specify what they understand for it, beyond not making mistakes (one of the components of said criteria):

F.: I think the important thing is that the teacher has the mastery of the class.

G.: Of course. Domain of the class and domain of the content.

F.: And the content, of course.

G.: Because if the teacher does not have the mastery of the content can plan the best class in the world that in practice will be terrible.

F.: And students perceive when they have failures. 


\section{Cognitive Suitability}

The reflection made by the teachers, from the point of view of the learning of the students (cognitive), is inclined to defend that the students build their own knowledge. This type of reflection gives us to understand that what is important for learning is that students activate relevant cognitive processes (generalization, intramathematical connections, changes of representation, conjectures, etc.). This type of argument puts the student as the protagonist of his learning and places the teacher in the plan of mediator of mathematical learning.

J.: Encourage students to think.

G.: Because if there is not a very expository class. You do not build with them, you just expose, you only present.

\section{Interactional Suitability}

In relation to the interaction in the classroom, the participants underline that the interaction between teacher and student must be more dialogical than masterful. Implicitly, they defend that the teacher must make an adequate presentation of the topic, interpreting the students' questions and using rhetorical resources to attract the attention of the students.

G.: It is not only to have control of the content, it is to have security. The teacher can know a lot about the content, but it does not help if he does not know how to express himself, he does not know how to communicate with the students.

F.: We have to start the class with something that invites them. That attracts.

G.: The students must be more protagonists of the class than only listeners.

\section{Mediational Suitability}

Contrary to the reflection made in the planning phase of the classroom, at this stage, the participants' value that one of the flaws of the classroom was the non-use of computer resources by students.

G.: But I think the only thing that was missing was manipulating the GeoGebra.

F.: Yes, sure.

G.: Because there, in school, you could not either.

F.: Yes, yes. The technology was limited. 


\section{Emotional Suitability and Ecological Suitability}

Contrary to the reflection carried out in the planning, where the participants did not comment on the emotional and ecological suitability of their design, in the stage of the analysis of the class implemented, the teachers point out the need to bring the content teaching to the reality of the students. This, according to them, is a way to motivate the students. From the emotional and ecological point of view, the participants argue that a selection of tasks of interest for the students should be made by proposing situations that allow valuing the usefulness of mathematics in daily and professional life.

G.: Another thing that I also think is important is to bring what is happening in your real life with the problems that are going to be used in the class. What was it that people did, using information from the Uber and the Taxi.

F.: We have to start the class with something that invites them. That attracts.

\section{DISCUSSION AND FINAL CONSIDERATIONS}

The first objective of this research, in relation to the training devices that use the LS methodology and the CDS, was to seek to understand how they propose the development of reflection on their own practice, seeking complementarities between both approaches. Regarding the devices that use the CDS, we see that they start with a non-patterned reflection phase in which participants are expected to implicitly use some indicators and components of the CDS. With regard to the devices that use the LS methodology, the review of the literature has allowed us to observe that, in the reflections made by the participants, some indicators and components of the CDS appear implicitly. This fact leads us to believe that conducting a Lesson Study can be a very good way to initiate the training courses that aim to teach the CDS tool as a guide to organize teacher reflection.

Our second objective was to verify, in an ad hoc designed case study, that what we had inferred from the LS literature review actually occurred: the implicit use of some CDS indicators and components in the reflection carried out by the participants. To do this, we investigated the role of the CDS in a Lesson Study experience, before the tool was taught to the participants in the framework of training device designed to combine both methodologies. The results obtained are consistent with those obtained in the review of the literature on Lesson Study: the CDS implicitly function as regularities in the discourse of teachers, without having been taught the use of this tool to guide their reflection

This is a result that is in line with those obtained in other research that have been interested in the role of the CDS in the reflection by professors or future teachers in training devices in which they have not been taught the use of this tool. For example, in the case of teaching staff in service, in Breda (2016), the characteristics of the didactic analysis carried out by the Brazilian teaching staff of the Mestrado Profissional em Matemática em Rede Nacional (Profmat) are presented to justify that their proposals are innovative 
and they represent an improvement in the teaching of mathematics. The results show that the justifications given by the teachers are based, above all, on the implicit use of the epistemic, ecological and mediational criteria and, to a lesser extent, on the use of the cognitive, emotional and interactional criteria.

Another example is in Morales \& Font (2017), where the reflections on the practice of the future teachers of secondary school mathematics in Costa Rica are analysed. We examined the portfolios that these elaborate during their practice, exploring them in light of the CDS construct. The results show that: 1) The teacher expresses comments in which aspects of description and/or explanation and/or assessment can be found, 2) emerge types of analysis that can be considered evidence of one of the facets (epistemic, cognitive, ecological, interactional, mediational and emotional) of the didactic-mathematical knowledge model of the mathematics teacher (Pino-Fan, Font \& Breda, 2017) and 3) when opinions are valued, they are implicitly or explicitly organized by some (few) indicators of the components of the CDS and the reflections that show them are superficial.

Morales and Font (in press) documents an investigation about the main elements of analysis and assessment that a teacher in service in Costa Rica uses when asked to comment on a class that she taught and that was recorded on video without any pattern of analysis previously established. In this case it was possible to show that the teacher uses more frequently, elements related to the epistemic and interactional CDS and the other evaluations that appear to a lesser extent could be classified with components and indicators of the other CDS, which, according to the authors, evidence that the use of the CDS, with its components and indicators, allowed to organize and classify the evaluations that the teacher made.

In relation to the results obtained in our research and those just discussed, one aspect to explain is the reason why the CDS function implicitly as regularities in the discourse of teachers without having been taught the use of this tool to guide their reflection. A plausible explanation (Breda, Font, \& Pino-Fan, 2018) is that the CDS reflect consensus on how it should be a good teaching of mathematics widely assumed in the community of educators (as); and it is plausible to think that the implicit use made by the teachers of the CDS is due to their training and previous experience, which makes them share in these consensus. Although this explanation does not seem very convincing in the case of teachers in initial training, as it is evident that they have not participated in the generation of consensus that are the support of the CDS.

Our research, together with others discussed above, is evidence that teachers' reflections, when they are assign value judgment and are oriented towards the improvement of the instructional processes, are organized, implicitly, using some indicators of the components of the CDS, although these have not previously been taught. For this reason, and with the aim of developing reflexive competence and the "meta" dimension of the mathematical didactic knowledge of mathematics teachers (Pino-Fan, Assis, \& Castro, 2015), we are designing and implementing training devices that combine the use of the LS methodology with the CDS as a tool to organize the reflection on its practice. 


\section{ACKNOWLEDGMENTS}

This work has been developed in the context of the research project in teacher training REDICE18-2000 (ICE-UB) and with the support of the program of Doctorate Plenary Abroad process number 88881.173616 / 2018-01 (Capes).

\section{REFERENCES}

Breda, A. \& Lima, V.M.R. (2016). Estudio de caso sobre el análisis didáctico realizado en un trabajo final de un master para profesores de matemáticas en servicio [Case Study on the Didactic Assessment over a Final Work of a Master for Mathematics Teachers in Service]. REDIMAT, 5(1), 74-103. Doi: 10.4471/redimat.2016.1955.

Breda, A. (2016). Melhorias no ensino de matemática na concepção de professores que realizam o mestrado Profmat no Rio Grande do Sul: uma análise dos trabalhos de conclusão de curso. [Improvements in the teaching of mathematics in the conception of professors who hold the Profmat Master's Degree in Rio Grande do Sul: an analysis of the master's thesis]. Tesis de Doctorado no publicada. Pontifícia Universidade Católica do Rio Grande do Sul. Porto Alegre, Brasil.

Breda, A., Font, V., \& Pino-Fan, L. (2018) Criterios Valorativos y Normativos en La Didáctica de las Matemáticas: el Caso del Constructo Idoneidad Didáctica [Evaluative and normative criteria in Didactics of Mathematics: the case of didactical suitability construct]. Bolema, 32(60), 255-278. Doi: 10.1590/1980-4415v32n60a13.

Breda, A., Pino-Fan, L. R., \& Font, V. (2017). Meta didactic-mathematical knowledge of teachers: criteria for the reflection and assessment on teaching practice. EURASIA Journal of Mathematics, Science and Technology Education, 13(6), 1893-1918. Doi: 10.12973/eurasia.2017.01207a.

Coelho, F. G., de Oliveira, A. T., \& Vianna, C. S. (2014). A metodologia da Lesson Study na formação de professores: uma experiência com licenciandos de Matemática [The methodology of the Lesson Study in teacher training: an experience with Mathematics graduates]. VIDYA, 34(2), 1-12.

Elliott, J. (1993). El cambio educativo desde la investigación-acción [Action Research for Educational Change] Madrid: Morata.

Felix, T. F. (2010). Pesquisando a melhoria de aulas de matemática segundo a proposta curricular do Estado de São Paulo, com a Metodologia da Pesquisa de Aula (Lesson Study) [Researching the improvement of mathematics classes following the curricular proposal of the state of São Paulo, with the methodology Lesson Study]. Tesis de maestria no publicada. Universidade Federal de São Carlos, São Carlos, Brasil.

Fernández, C., \& Yoshida, M. (2004). Lesson study: a Japanese approach to improving mathematics teaching and learning. Mahwah, NJ: Erlbaum.

Font, V., Breda, A., \& Pino-Fan, L. (2017). Análisis didáctico en un trabajo de fin de máster de un futuro professor [Didactic analysis in a final work of a master for mathematics teachers in pre-service]. En J.M. Muñoz-Escolano, A. Arnal-Bailera, P. Beltrán-Pellicer, M.L. Callejo y J. Carrillo (Eds.), Investigación en Educación Matemática XXI (pp.247-256). Zaragoza: SEIEM. 
Font, V., Planas, N., \& Godino, J. D. (2010). Modelo para el análisis didáctico en educación matemática [A model for the study of mathematics teaching and learning processes]. Infancia y Aprendizaje, 33(1), 89-105.

Giacomone, B., Godino, J. D., \& Beltrán-Pellicer, P. (2018). Desarrollo de la competencia de análisis de la idoneidad didáctica en futuros profesores de matemáticas [Developing the mathematics teachers' didactical suitability analysis competence]. Educação e Pesquisa, 44, 1-21. Doi: 10.1590/s1678-4634201844172011.

Godino, J. D. (2013). Indicadores de idoneidad didáctica de procesos de enseñanza y aprendizaje de las matemáticas [Indicators of didactical suitability for mathematics teaching and learning processes]. Cuadernos de Investigación y Formación en Educación Matemática, 11, 111-132.

Godino, J. D., Batanero, C., \& Font, V. (2007). The onto-semiotic approach to research in mathematics education. ZDM. The International Journal on Mathematics Education, 39(1), 127-135.

Hart, L. C., Alston, A. S., \& Murata, A. (2011). Lesson Study Research and Practice in Mathematics Education. Netherlands: Springer.

Kaiber, T., Lemos, A., y Pino-Fan, L. (2017). Enfoque Ontossemiótico do Conhecimento e da Instrução Matemática (EOS): um panorama das pesquisas na América Latina [OntoSemiotic Approach to Mathematical Cognition and Instruction (OSA): an overview of research in Latin America]. Perspectivas da Educação Matemática, 10(23), 531-552.

Lewis, C. C. (2002). Lesson study: A handbook of teacher-led instructional change.

Research for Better Schools. Inc. \& Global Education Resources: LLC.

Morales, Y. \& Font, V. (2017). Análisis de la reflexión presente en las crónicas de estudiantes en formación inicial en educación matemática durante su periodo de práctica professional [Analysis of the refection present in the chronicles of students in initial training in Mathematics Education during their teaching internship]. Acta Scientiae, 19(1), 122-137.

Morales, Y., y Font, V. (en prensa). Valoración realizada por una profesora de la idoneidad de su clase de matemáticas [Evaluation by a teacher of the suitability of her math class]. Educação e Pesquisa.

Moreira, C. B., Gusmão, T. C. R. S., \& Font, V. (2018). Mathematical Tasks for the Development of Space Perception in Early Childhood Education: potentials and limits. Bolema: Boletim de Educação Matemática, 32(60), 231-254. Doi: 10.1590/1980-4415v32n60a12.

Murata, A., \& Takahashi, A. (2002). Vehicle To Connect Theory, Research, and Practice: How Teacher Thinking Changes in District-Level Lesson Study in Japan. Teaching children mathematics, 436-443.

National Council of Teachers of Mathematics (Ed.). (2000). Principles and standards for school mathematics (Vol. 1). Reston, VA: NCTM.

Pino-Fan, L., Assis, A., \& Castro, W. F. (2015). Towards a methodology for the characterization of teachers' didactic -mathematical knowledge. Eurasia Journal of Mathematics, Science \& Technology Education, 11(6), 1429-1456. Doi: 10.12973/ eurasia.2015.1403a. 
Pino-Fan, L., Font, V., \& Breda, A. (2017). Mathematics teachers' knowledge and competences model based on the onto-semiotic approach. En B. Kaur, W. K. Ho, T. L. Toh \& B. H. Choy (Eds.), Proceedings of the 41st Conference of the International Group for the Psychology of Mathematics Education (Vol. 4, pp.33-40). Singapur: PME.

Pochulu, M., Font, V., \& Rodríguez, M. (2016). Desarrollo de la competencia en análisis didáctico de formadores de futuros profesores de matemática a través del diseño de tareas [Development of the competence in didactic analysis of training of future mathematics teachers through task design]. Revista Latinoamericana de Investigación en Matemática Educativa-RELIME, 19(1), 71-98. Doi: 10.12802/relime.13.1913.

Ramos, A. B. (2006). Objetos personales, matemáticos y didácticos, del profesorado y cambios institucionales. El caso de la contextualización de las funciones en una Facultad de Ciencias Económicas y Sociales [Personal, mathematical and didactic objects of the teaching staff and institutional changes. The case of the contextualization of functions in a Faculty of Economic and Social Sciences]. Tesis de doctorado no publicada. Universitat de Barcelona, Barcelona, España.

Schön, D. A. (1983). The Reflective Practitioner: how professionals think in action. New York: Basic Books.

Seckel, M. J. (2016). Competencia en análisis didáctico en la formación inicial de profesores de educación básica con mención en matemática [Competence in didactic analysis in the initial formation of teachers of basic education with mention in mathematics]. Tesis de Doctorado no publicada. Universitat de Barcelona, España.

Seckel, M. J., y Font (en prensa). Competencia reflexiva en formadores del profesorado de matemática [Reflective competence in mathematics teacher educators]. Magis. Utimura, G. (2015). Docência compartilhada na perspectiva de estudos de aula (lesson study): um trabalho com as figuras geométricas espaciais no quinto ano [Shared teaching from the perspective of Lesson Study: a work with spatial geometrical figures in the fifth year]. Tesis de maestria no publicada. Universidade Cruzeiro do Sul, São Paulo, SP, Brasil.

Wang-Iverson, P., \& Yoshida, M. (Eds.). (2005). Building our understanding of lesson study. Research for Better Schools, Inc. \& Global Education Resources: LL. 